\title{
Alterstice
}

Revue internationale de la recherche interculturelle

International Journal of Intercultural Research

Revista International de la Investigacion Intercultural

\section{Back to school! (Mis)trust and acculturation processes among immigrant students at Campus Montreal}

\section{Sébastien Arcand, Chantale Asselin et Fasal Kanouté}

Volume 6, numéro 1, 2016

Prendre en compte la diversité à l'école

URI : https://id.erudit.org/iderudit/1038279ar

DOI : https://doi.org/10.7202/1038279ar

Aller au sommaire du numéro

Éditeur(s)

Alterstice

ISSN

1923-919X (numérique)

Découvrir la revue

Citer cet article

Arcand, S., Asselin, C. \& Kanouté, F. (2016). Back to school! (Mis)trust and acculturation processes among immigrant students at Campus Montreal. Alterstice, 6(1), 57-72. https://doi.org/10.7202/1038279ar

\section{Résumé de l'article}

This article focuses on the academic perseverance of Permanent Resident University Students (PRUS) in the three post-secondary institutions that make up Campus Montréal (University of Montreal, HEC Montreal, and Polytechnique Montreal). Returning to school is often framed as a way for new immigrants to update their education and level the playing field in order for them to gain access to the same labor market opportunities as those who are born in the host society. We present the results of a study carried out with 426 respondents of an online survey and 44 participants of group interviews with recent PRUS in Montreal. Using the concepts of acculturation process and (mis)trust, this qualitative inductive analysis highlights the main constraints experienced by the respondents, which is reflected in their social representations of the integration process and their decision to return to university. In this context, and given the apparent inequalities in terms of intergroup relations, returning to university might in fact be detrimental to their stated goal of rapid and successful integration into the host society, particularly the labor market. Consequently, in a migratory context, the return to university might, in fact, have a demoralizing effect since the experience foreshadows the barriers, systemic or otherwise, that these professionals may encounter in their efforts to enter the labor market. 


\title{
7
}

ARTICLE THÉMATIQUE

\section{Back to school! (Mis)trust and acculturation processes among immigrant students at Campus Montreal}

\author{
Sébastien Arcand ${ }^{1}$, Chantale Asselin ${ }^{2}$ et Fasal Kanouté ${ }^{3}$
}

\section{Résumé}

This article focuses on the academic perseverance of Permanent Resident University Students (PRUS) in the three post-secondary institutions that make up Campus Montréal (University of Montreal, HEC Montreal, and Polytechnique Montreal). Returning to school is often framed as a way for new immigrants to update their education and level the playing field in order for them to gain access to the same labor market opportunities as those who are born in the host society. We present the results of a study carried out with 426 respondents of an online survey and 44 participants of group interviews with recent PRUS in Montreal. Using the concepts of acculturation process and (mis)trust, this qualitative inductive analysis highlights the main constraints experienced by the respondents, which is reflected in their social representations of the integration process and their decision to return to university. In this context, and given the apparent inequalities in terms of intergroup relations, returning to university might in fact be detrimental to their stated goal of rapid and successful integration into the host society, particularly the labor market. Consequently, in a migratory context, the return to university might, in fact, have a demoralizing effect since the experience foreshadows the barriers, systemic or otherwise, that these professionals may encounter in their efforts to enter the labor market.

\section{Rattachement des auteurs \\ ${ }^{1}$ Département de management, HEC Montréal (Montréal), Canada ; ${ }^{2}$ chercheure indépendante ; ${ }^{3}$ Université de Montréal, Montréal (Canada)}

\section{Correspondance}

sebastien.arcand@hec.ca

\section{Mots clés}

academic and professional integration, acculturation, intergroup relations, trust, social representations

\section{Pour citer cet article}

Arcand, S., Asselin, C. et Kanouté F. (2016). Back to school! (Mis)trust and acculturation processes among immigrant students at Campus Montreal. Alterstice, 6(1), 57-72. 


\section{Introduction}

Immigrant populations constitute a large and attractive pool of potential candidates for professional and postsecondary educational institutions. Despite the many studies carried out on the participation of immigrants in the educational systems of their host country, very few have focused on permanent resident immigrants ${ }^{1}$. The category of Permanent Resident University Students (PRUS) is particularly interesting since it offers an opportunity to examine the experiences of individuals who are likely to remain in the host country and actively contribute to its socioeconomic development. Their perseverance within the academic system becomes a personal and collective interest for the host society. In this article, the issue of perseverance will be discussed by using two concepts that put the individual (in this case the PRUS) at the centre of the adaptation process and academic success. These distinct yet complementary concepts are trust and acculturation. Through these individuals' social representations (Moscovici, 1961; Rateau and al., 2011), both concepts highlight the nature of the interactions that PRUS encounter with institutions of the host society (in this case the university), as well as their social relations with other individuals in an academic context. It is important to note that although we have used an individualistic approach, we do not ignore the systemic effects on PRUS and their successful integration into Québec's university system. However, by analysing the perceptions of these international students we aim to gain a better understanding of their experiences and, consequently, the possibilities that they achieve their academic goals while contributing to their host society in the short and medium term.

A number of studies have illustrated the issues surrounding acculturation in relation to international students and longer established immigrant individuals (Duchesne, 2010; Duclos, 2011; Grayson, 2001; Hung and Hyun, 2001; Owens and Massey, 2011). PRUS' integration requires the implementation of specific acculturation mechanisms to increase and improve trust between them and institutions within which they take part and want to belong (Berry, 2008). The social psychologist Berry $(1997 ; 2008)$ has carried out inspirational research that emphasizes the socialisation experiences that an individual acquires before settling in a different cultural context: acculturation is a process of learning in new social and cultural contexts after one has become socialised into an earlier one (Berry, 2008). For the purpose of this article we define acculturation as the global process of psychological and sociocultural adaptation individuals experience when confronted with one or more cultures other than the one in which they were first socialized (Berry, Phinney, Sam \& Vedder, 2006; Kanouté, 2002; Wang, Schwartz and Zamboanga, 2010).

With regards to the concept of trust, it holds a prominent position in social and human sciences, particularly in sociology, which constitutes the cornerstone of our framework (Durkheim, 1895/1964; Luhmann, 1979; Boudon, 1989, 1992; Giddens, 1978; Berger and Luckmann, 1966). Trust became a fundamental structural element of modern societies while being dynamic and taking multidimensional shapes and forms. More recently, the notion of trust has been studied by scholars, including Nooteboom (2002) who looks at its diverse forms and foundations and Möllering (2006) who links trust with other important concepts of modernity, such as rationality, reflexivity or routine. In a study carried out in Northern Ireland on intergroup relations, Kenworthy and al. (2016) highlight the importance of cross-group friendships for the development of intergroup trust. From an organizational perspective, Downey and al. (2015) reveal that diversity management practices increase levels of trust within organizations, which contributes positively to employee engagement and retention rates. We draw on these studies for our research as they enable us to emphasize the importance of action and interactions in the analysis of the proposed relationship among trust and social relations with the acculturation process (Dumouchel, 2005). As a result, trust is built from multiple interactions and the interpretations that individuals make of them. For example, if PRUS have had negative experiences with people from another ethnocultural group, this could explain a weakened level of trust with regards to these groups. On the other hand, the integration of newcomers within organizations and institutions would be facilitated by fostering openness and adequate preparation with regards to diversity. Consequently, the individual's level of trust in the organization, as well as the host society, will likely be higher.

\footnotetext{
${ }^{1}$ In Canada, the term Permanent Resident refers to those immigrants who are in the process of obtaining their citizenship. This status offers them nearly all the advantages of citizenship, with the exception of the right to vote. The majority of permanent residents apply for citizenship within five years.
} 
When it comes to studying the notion of trust, an analysis that is too predictive or general may result in overlooking the specific and changing nature of trust in modern society. In this regard, examples from the economic world are indicative of this "fluidity" inherent in trust as it can quickly transform into suspicion after specific events.

Hence, (mis)trust between PRUS and universities, as well as their acculturation processes, play essential roles in understanding their strategies to integrate and succeed in their academic journey (Asselin, 2014; ChatelDeRepentigny, Montmarquette and Vaillancourt, 2011). The issue of academic perseverance at the post-secondary level has been raised in studies conducted in various national contexts, including France (Adangnikou, 2008; Rege Colet, 2008), Morocco (Chiadli, Jebbah and De Ketele, 2010), England (Ashwin, 2009) and the UK (Gray, Galton, McLaughlin, Clarke and Symonds, 2011). The factors linked to success at the university level are numerous and complex. Studying these factors therefore implies a deeper reflection on perseverance in relation to university reform (Alava and Langevin, 2001; Viens, Lepage and Karsenti, 2010) and effectiveness in post-secondary pedagogy (Loiola and Romainville, 2008). These studies highlight aspects of the university experience that may contribute to academic stress. Managing this stress through individual efforts as well as institutional measures contributes greatly to academic perseverance (Bouteyre, 2008). Béchard (2008) examined major contributions to postsecondary pedagogy and based his research on three major research publications - Res America (RES) for francophone countries, Studies in Higher Education (SHE) for Commonwealth countries, and Innovative Higher Education (IHE) for the United States - covering the period from 1976 to 2003. This broad meta-analysis demonstrates that, to this day, very little research has examined the issues surrounding post-secondary pedagogy while also taking into account the management of ethnocultural diversity in a university context.

In terms of the academic perseverance of permanent resident students, the fear of encountering the widely documented barriers to integration into the labor force may have a negative impact on program completion rates (Arcand, Lenoir-Achdjian and Helly, 2009; Boudarbat and Cousineau, 2010; Chicha, 2009; Chicha and Charest, 2010). Boudarbat and Cousineau (2010) found a negative association between being enrolled in or having completed a program of study after immigrating and the likelihood of finding employment that was entirely or mainly consistent with their expectations. The results of the study carried by out Sauvé et al. (2007), which consisted of a survey completed by 216 first-year students in three major francophone universities in the province of Quebec, as well as a number of semi-structured interviews, divided the factors contributing to abandonment and perseverance into five categories: 1) personal dimensions, 2) prerequisites, 3) personal investment in studies, 4) knowledge of the language of instruction, 5) learning strategies. The authors present a series of observations, including the fact that those students who had abandoned their studies tended to be less sociable and feel less well equipped in terms of their learning strategies. As for those who persevered, they tended to be better able to maximize their human and financial investment in their studies, and generally felt that strong institutional support was a motivational factor.

\section{Research objectives and theoretical framework}

There are a number of high quality of articles dealing with international and immigrant students, yet very few of them focus on the specific aspects of acculturation and trust as pathways to approach the experience of PRUS. We aim to fill in this gap by examining the relationships they develop with the university community, as well as the society in which they have become stakeholders. Given that the concepts of (mis)trust and acculturation are put forward, we suggest that academic perseverance is a function of the nature of trust and the level of acculturation of these individuals. As a result, the three specific objectives in relation to the collected data are as follows:

1. Identify and analyze the personal factors that contribute to, or hinder, the academic perseverance of permanent resident students;

2. Identify and analyze the factors relating to the broader process of acculturation to the host society that contribute to, or hinder, the academic perseverance of permanent resident students.

3. Identify the possible effects of trust in institutions and social interactions and acculturation processes on permanent resident university students' social representations of their status and role. 
This study is guided by the following question: How does the university experience of permanent resident students affect these individuals in terms of academic perseverance and abandonment? We propose that PRUS experience a certain degree of isolation, both in academia and the wider society, which, in turn, contributes to a specific acculturation process that may hinder their academic perseverance and ultimately their integration into the host society, particularly the labor market. As such, our research allows us to examine the progress of these permanent resident students, with a particular interest in their societal and institutional adaptation. In order to gain a broader understanding of academic perseverance among PRUS, we built a framework based on the concepts of acculturation and trust that allows us to analyze converged data referring to relationships of (mis)trust between PRUS and people in the university community, as well as their efforts to integrate into the society in which they have become stakeholders.

\section{Data sample and collection}

We conducted a study among permanent resident students (PRUS) enrolled at the University of Montreal (UofM and its two affiliated institutions, HEC Montreal and Polytechnique Montreal, collectively known as Campus Montreal ${ }^{2}$. In total, 426 PRUS responded to the online questionnaire (282 enrolled at the UofM, 94 at HEC and 50 at Polytechnique). Aside from the results obtained from the online questionnaires, we have also included excerpts from the focus groups attended by 44 PRUS of which 32 are enrolled at the UofM, eight at HEC, and four at Polytechnique. ${ }^{3}$ In the following section we present the qualitative data as a means of supporting the quantitative results presented in the tables. In order to protect the anonymity of our respondents, the only information we provide is whether they participated in a focus group (FG), as well as the institution they attend.

The approach used to analysis the data was qualitative and inductive, which integrates a descriptive analysis of emerging data from the online questionnaire. This approach enabled us to divide the data into thematic groups (Creswell, 2009; Taylor-Powell and Renner, 2003; Miles and Huberman, 1994) and identify the most recurring semantic categories, which in this case were: a) Networks and involvement in associations and b) Solitude and Exclusion. The Figure 1 schematizes the analytical process:

\section{Figure 1. Analytical Model}

\section{1st level of analysis}

\section{Quantitative Data}

On-line questionnaire

( $n=416)$

\section{Qualitative Data}

Focus Groups and one-on-one

interviews

$(n=44)$

\section{Proposals}

$2^{\text {nd }}$ Level of analysis

\author{
The sociodemographic profile of PRUS \\ favored their integration and \\ university perseverance
}

Trust: Networks and Involvement

Social representations of PRUS are in accordance with their sociodemographic profile
Acculturation: Perceived level of Solitude and Exclusion

\footnotetext{
${ }^{2}$ The research upon which this article is based is indeed quite multidisciplinary (drawing on notions from fields as varied as Education, Management, Political Science, Nursing, Social Work, and Industrial Relations), and the results have been compiled by a team of ten university researchers from six Quebec institutions - five of which are located in the province's largest city, Montreal, and one from the provincial capital, Quebec. Given the specificities of each of these institutions, and the large quantity of qualitative and quantitative data collected, we have chosen to analyze this data separately according to institution or group of institutions.

${ }^{3}$ It is worth noting that approximately 75\% of all immigrants to the province of Quebec settle in Montreal (MICC, 2013).
} 


\section{Findings}

While we found no information pertaining specifically to the countries of origin of PRUS attending Campus Montreal, the following chart presents the regions of origin for all international students, including permanent resident students, at Campus Montreal for the 2009-2010 academic year. It provides an overview of the cultural diversity among students enrolled at Campus Montreal (Figure 2):

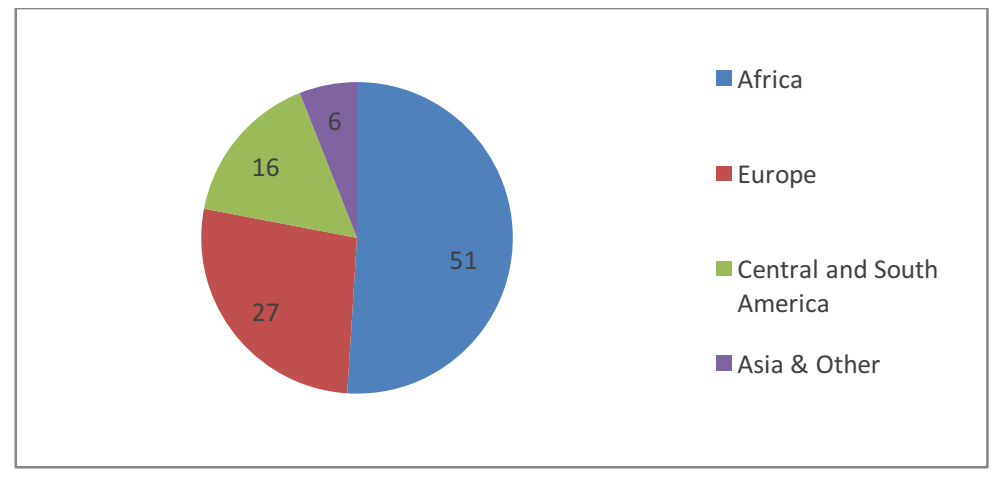

Figure 2. Permanent resident and international students by region

The age range for our respondents varied considerably (Table 1). The largest group was made up of 15 to 34 yearolds (over 60\%).

Table 1. Age of respondents to the online survey

\begin{tabular}{cccccccccccccccccccccccc}
\hline & \multicolumn{2}{c}{$15-19$} & \multicolumn{2}{c}{$20-24$} & \multicolumn{2}{c}{$25-29$} & \multicolumn{2}{c}{$15-29$} & \multicolumn{2}{c}{$30-34$} & \multicolumn{2}{c}{$35-39$} & & $40-44$ & \multicolumn{2}{c}{$45-49$} & \multicolumn{2}{c}{$50+$} & \multicolumn{2}{c}{ Total } \\
& $\mathrm{N}$ & $\%$ & $\mathrm{~N}$ & $\%$ & $\mathrm{~N}$ & $\%$ & $\mathrm{~N}$ & $\%$ & $\mathrm{~N}$ & $\%$ & $\mathrm{~N}$ & $\%$ & $\mathrm{~N}$ & $\%$ & $\mathrm{~N}$ & $\%$ & $\mathrm{~N}$ & $\%$ & $\mathrm{~N}$ & $\%$ \\
\hline UDM & 2 & 0,7 & 31 & 11,0 & 50 & 17,7 & 83 & 29,4 & 86 & 30,5 & 61 & 21,6 & 34 & 12,1 & 9 & 3,2 & 9 & 3,2 & 282 & 100 \\
HEC & 0 & 0,0 & 7 & 7,4 & 19 & 20,2 & 26 & 27,7 & 34 & 36,2 & 24 & 25,5 & 5 & 5,3 & 4 & 4,3 & 1 & 1,1 & 94 & 100 \\
Pol. & 3 & 0,6 & 8 & 16,0 & 13 & 26,0 & 24 & 48,0 & 15 & 30 & 10 & 20,0 & 1 & 2,0 & 0 & 0,0 & 0 & 0,0 & 50 & 100 \\
\hline Total & 5 & 0,9 & 46 & 10,0 & 82 & 20,2 & 133 & 31,1 & 135 & 31,3 & 95 & 22,5 & 40 & 9,7 & 13 & 3,6 & 10 & 1,8 & 426 & 100 \\
\hline
\end{tabular}

Pol., Polytechnique; UDM, University of Montreal.

The relatively advanced age of the respondents, as compared with non-PRUS, could explain the difficulty encountered by older members (35 years and older) of this group in socializing with their generally younger classmates, which can exacerbate their perceived level of solitude and exclusion. In addition, the majority of the respondents are recent immigrants, with 77\% of them having settled in the province of Quebec in 2008 or after. $51 \%$ of the respondents came to Quebec as regular skilled workers, and $45.3 \%$ of them confirmed that they experienced difficulties finding a job specifically related to their field of study after arrival. Given that this (negative) experience prompted them to return to university, their perceived level of solitude and exclusion was higher, which will be discussed below. However, we begin with a discussion of how networks and involvement in associations may have an impact on trust and acculturation processes.

\section{Grouping \#1: Networks and involvement in associations}

In the online survey, we asked our PRUS respondents whether they felt comfortable at university. The answers reveal that the majority (62\%) of respondents did indeed feel at ease in this setting. However, when asked if it was easy to establish relationships between people from all origins their reactions were more mixed. These results are presented in Tables 2 and 3. 
Table 2. Q38-3 "You take initiatives to make friends and to integrate social networks"

\begin{tabular}{|c|c|c|c|c|c|c|c|c|c|c|c|c|}
\hline \multirow{2}{*}{ Q38-3 } & \multicolumn{2}{|c|}{1} & \multicolumn{2}{|c|}{2} & \multicolumn{2}{|c|}{3} & \multicolumn{2}{|c|}{4} & \multicolumn{2}{|c|}{5} & \multicolumn{2}{|c|}{ Total } \\
\hline & $\mathrm{N}$ & $\%$ & $\mathrm{~N}$ & $\%$ & $\mathrm{~N}$ & $\%$ & $\mathrm{~N}$ & $\%$ & $\mathrm{~N}$ & $\%$ & $\mathrm{~N}$ & $\%$ \\
\hline $\begin{array}{c}\text { University of } \\
\text { Montreal }\end{array}$ & 26 & 9,5 & 65 & 23,6 & 102 & 37,1 & 77 & 28,0 & 5 & 1,8 & 275 & 100 \\
\hline HEC & 7 & 7,4 & 26 & 27,7 & 39 & 41,5 & 21 & 22,3 & 1 & 1,1 & 93 & 100 \\
\hline $\begin{array}{c}\text { Poly- } \\
\text { technique }\end{array}$ & 1 & 2,0 & 7 & 14,3 & 30 & 61,2 & 10 & 20,4 & 1 & 2,0 & 49 & 100 \\
\hline Total & 34 & 8,1 & 98 & 23,4 & 171 & 40,9 & 108 & 25,8 & 7 & 1,7 & 418 & 100 \\
\hline
\end{tabular}

Note: 1= Completely Disagree 2= Somewhat Disagree 3= Somewhat Agree 4= Completely Agree 5= Not Applicable

Table 3. Q38-2 “It is easy to establish social interactions between different ethnic groups?”

\begin{tabular}{|c|c|c|c|c|c|c|c|c|c|c|c|c|c|c|}
\hline \multirow{2}{*}{ Q38-2 } & \multicolumn{2}{|c|}{1} & \multicolumn{2}{|c|}{2} & \multicolumn{2}{|c|}{ Total $1+2$} & \multicolumn{2}{|c|}{3} & \multicolumn{2}{|c|}{4} & \multicolumn{2}{|c|}{5} & \multicolumn{2}{|c|}{ Total } \\
\hline & $\mathrm{N}$ & $\%$ & $\mathrm{~N}$ & $\%$ & $\mathrm{~N}$ & $\%$ & $\mathrm{~N}$ & $\%$ & $\mathrm{~N}$ & $\%$ & $\mathrm{~N}$ & $\%$ & $\mathrm{~N}$ & $\%$ \\
\hline $\begin{array}{l}\text { University of } \\
\text { Montreal }\end{array}$ & 43 & 15,6 & 75 & 27,3 & 118 & 42,9 & 94 & 34,2 & 52 & 18,9 & 11 & 4,0 & 275 & 100 \\
\hline HEC & 15 & 16,1 & 31 & 33,3 & 46 & 49,5 & 35 & 37,6 & 11 & 11,8 & 1 & 1,1 & 93 & 100 \\
\hline $\begin{array}{c}\text { Poly- } \\
\text { technique }\end{array}$ & 5 & 10,2 & 14 & 28,6 & 19 & 38,8 & 19 & 38,8 & 10 & 20,4 & 1 & 2,0 & 49 & 100 \\
\hline Total & 63 & 13,8 & 120 & 25,9 & 183 & 39,8 & 148 & 39,4 & 73 & 17,0 & 13 & 3,8 & 417 & 100 \\
\hline
\end{tabular}

Note: 1= Completely Disagree 2= Somewhat Disagree 3= Somewhat Agree 4= Completely Agree 5= Not Applicable

Although most respondents felt comfortable in a university setting, $40 \%$ found that interactions between ethnic groups were difficult to establish:

The problem I've had, and still have, is in finding a steady teammate, someone I can have an exchange with. This isn't easy to find here, human relations. When we have the opportunity to work with someone on a group project, we try to take full advantage of these moments because it's not always easy to find a partner or a team... (FG, Polytechnique).

This same person, referring to differences between his/her country of origin and the host society, adds:

Interactions can be very beneficial. At home, in my country, we were used to working in groups of three, four, five... Here, it's not easy. Even finding people from the same country as me, it's not easy. Perhaps it's because everyone has their own thing to do, there are constraints... (FG, Polytechnique)

Other participants mentioned similar difficulties:

I had to deal with my first team project with Quebecers. I was probably their first-ever contact with an immigrant and it went pretty badly. So, the challenge was completing the assignment. I wasn't used to this. I'm much more mathematical: $1+1=2$ and that's as far as it goes! (FG, Uof M).

I was a bit traumatized by the mandatory team projects. When you don't know anyone in the room and you have to make teams based only on physical appearances, when in theory we're all humans... It's very complicated and after a while you understand that if you are French you are not well regarded because of all the stereotypes. So you're classified as a French person and as a foreigner. You start to seek out other foreigners because at least they will accept you. I had a hard time with this because these are choices you only make by default (FG, Uof M) 
Two participants (FG, HEC) did, however, mention that dealing with Quebecers during team projects had allowed them to better understand both the Quebecois culture and accent. It is also interesting to note that certain participants felt it was more difficult to create relationships at the undergraduate level than as graduate students. As PRUS tend to be older than students born in Québec, age may also have an influence on their experiences at the undergraduate level:

There's not only the "immigration" issue. These are young people, and we are interested in other things. They never say "hello" in class. I am always the one who initiates things, who reaches out to them. Sometimes I make up questions, just to have a bit of communication. We need to interact... (FG, Uof M)

The communication issue was raised by PRUS respondents on several occasions, and is closely related to the fact that language plays a determinant role in the context of Quebec. Indeed, the majority of PRUS we met was were not native French speakers or did not necessarily master the subtleties of Quebecois French. However, as noted above, the data reveals that establishing relationships with Quebecois students is easier at the graduate level.

That was Bachelor's courses, but in graduate level courses there are many international students. Nobody knows anyone else, so it's easier to say "ok, let's work together!" (FG, Polytechnique)

For one student the difficulty does not reside in working on team projects, but rather in continuing the relationships created at university in their regular social life:

At school, everything is quite good. Sometimes we have classes with a whole community, people who come from all over. It's very multicultural. We also meet Quebecers. The interesting thing about working with native Quebecers is that the relationships we form in class very rarely carry over outside the classroom. They're people who, it must be said, are quite self-centered, even if they are open to others' points of view. They're (Quebecers) people who open up but then close up very quickly afterward [...]. Quebecers are good people, but they won't necessarily make the first step or, when you reach out to them are not very welcoming, except when they are forced to by the professor because he has already defined the teams [...] because here many of the assignments are done in teams. (FG, Polytechnique)

Beyond highlighting the difficulty of creating long-term relationships with Quebecois students, this excerpt demonstrates how certain professors choose to impose predefined teams on their students. At HEC Montreal, some professors even make a point of creating multicultural teams, with the aim of maintaining a certain degree of cohesion in the classroom. Table 4 presents the results obtained for the question on whether it is easier to create relationships with immigrant and/or international students, or with Quebecers.

Table 4. Q38-4 "It is easier to interact with immigrant and international students"

\begin{tabular}{|c|c|c|c|c|c|c|c|c|c|c|c|c|c|c|}
\hline \multirow{2}{*}{ Q38-4 } & \multicolumn{2}{|c|}{1} & \multicolumn{2}{|c|}{2} & \multicolumn{2}{|c|}{ Total $1+2$} & \multicolumn{2}{|c|}{3} & \multicolumn{2}{|c|}{4} & \multicolumn{2}{|c|}{5} & \multicolumn{2}{|c|}{ Total } \\
\hline & N & $\%$ & $\mathrm{~N}$ & $\%$ & $\mathrm{~N}$ & $\%$ & $\mathrm{~N}$ & $\%$ & $\mathrm{~N}$ & $\%$ & $\mathrm{~N}$ & $\%$ & $\mathrm{~N}$ & $\%$ \\
\hline $\begin{array}{c}\text { University of } \\
\text { Montreal }\end{array}$ & 17 & 6,2 & 39 & 14,1 & 56 & 20,3 & 88 & 31,9 & 119 & 43,1 & 13 & 4,7 & 276 & 100 \\
\hline HEC & 4 & 4,3 & 15 & 16,0 & 19 & 20,2 & 22 & 23,4 & 51 & 54,3 & 2 & 2,1 & 94 & 100 \\
\hline $\begin{array}{c}\text { Poly- } \\
\text { technique }\end{array}$ & 2 & 4,1 & 3 & 6,1 & 5 & 10,2 & 20 & 40,8 & 24 & 49,0 & 0 & 0,0 & 49 & 100 \\
\hline Total & 23 & 7,1 & 57 & 14,9 & 80 & 22,0 & 130 & 32,7 & 194 & 40,3 & 15 & 5,0 & 419 & 100 \\
\hline
\end{tabular}

Note: 1= Completely Disagree 2= Somewhat Disagree 3= Somewhat Agree 4= Completely Agree 5= Not Applicable 
The results presented in table 4 show that respondents had a difficult time establishing ties with members of the majority group. While the specific reasons for this situation are still unclear, it is evident that the respondents truly feel there is a problem, which is likely a factor that aggravates the issue. The data on their participation in social networks provides a better idea of the lack of interactions between PRUS and Quebecois students (Table 5).

Table 5 Q38-8 “Are you involved in student associations?”

\begin{tabular}{|c|c|c|c|c|c|c|c|c|c|c|c|c|c|c|}
\hline \multirow{2}{*}{ Q38-8 } & \multicolumn{2}{|c|}{1} & \multicolumn{2}{|c|}{2} & \multicolumn{2}{|c|}{ Total $1+2$} & \multicolumn{2}{|c|}{3} & \multicolumn{2}{|c|}{4} & \multicolumn{2}{|c|}{5} & \multicolumn{2}{|c|}{ Total } \\
\hline & $\mathrm{N}$ & $\%$ & $\mathrm{~N}$ & $\%$ & $\mathrm{~N}$ & $\%$ & $\mathrm{~N}$ & $\%$ & $\mathrm{~N}$ & $\%$ & $\mathrm{~N}$ & $\%$ & $N$ & $\%$ \\
\hline $\begin{array}{c}\text { University of } \\
\text { Montreal }\end{array}$ & 144 & 52,7 & 62 & 22,7 & 206 & 75,5 & 27 & 9,9 & 9 & 3,3 & 31 & 11,4 & 273 & 100 \\
\hline HEC & 54 & 58,1 & 18 & 19,4 & 72 & 77,4 & 5 & 5,4 & 6 & 6,5 & 10 & 10,8 & 93 & 100 \\
\hline $\begin{array}{c}\text { Poly- } \\
\text { technique }\end{array}$ & 18 & 37,5 & 10 & 20,8 & 28 & 58,3 & 10 & 20,8 & 6 & 12,5 & 4 & 8,3 & 48 & 100 \\
\hline Total & 216 & 49,4 & 90 & 22,5 & 306 & 71,8 & 42 & 10,9 & 21 & 5,3 & 45 & 11,9 & 414 & 100 \\
\hline
\end{tabular}

Note: 1= Completely Disagree 2= Somewhat Disagree 3= Somewhat Agree 4= Completely Agree 5= Not Applicable

As part of the data collection process, we wanted to determine whether there is a link between the ethnic composition of the respondents' social networks and their involvement in associations, both at school and in the broader community. We asked the following question: "How important is social participation: at university, in your neighborhood? Are you involved in politics, your community, unions or social networks with immigrant or nonimmigrant friends"?:

Since my arrival, for the last 18 months, I have had no social activities. The little time I have had, I have used to rest. Since I have gone back to school, I found a group of Cameroonians. We get together to exchange information about employment and to share our experiences. I work as an auditor, and I also have a job managing new technologies (internet, developing websites). (FG, Polytechnique)

There is a group of Latino people - not just Colombians- and these are my closest friends. There is also a group of Colombians. Here, at university, I'm always with Quebecers and Colombians. I also have a little group - there are three of us - of Latina girls, and every month we get together to talk about our... We make lists of things we want to accomplish during the year, and every month we get together to talk about this and try to help each other out. (FG, Polytechnique)

Yes. We talk about education, relationships, university, work... We talk about this and we do exercises in a little book. We read one chapter every time and we do the exercises. The other one is with colleagues. Yes, it was difficult. I wanted to make a group with Quebecers, but I never got the chance; it was more with Colombians, French people... (FG, Polytechnique)

The literature on the integration of immigrants has clearly demonstrated that participation in groups and associations, is a significant transitory stage for a large number of recent immigrants, although it does not apply to all of them.

\section{Grouping \#2: Solitude and exclusion}

The final section of results covers certain difficulties that often appear in the literature, such as feelings of solitude and exclusion. The data presented below pertains to PRUS' feelings of social isolation, discrimination, and latent racism, as well as feelings of a decline in social status compared to their situation in their country of origin. The results presented in Table 6 show that feelings of social isolation are predominant among our sample. 
Table 6 Q48-4 "You have felt socially isolated"

\begin{tabular}{|c|c|c|c|c|c|c|c|c|c|c|c|c|c|c|}
\hline \multirow{2}{*}{ Q48-4 } & \multicolumn{2}{|c|}{1} & \multicolumn{2}{|c|}{2} & \multicolumn{2}{|c|}{ Total $1+2$} & \multicolumn{2}{|c|}{3} & \multicolumn{2}{|c|}{4} & \multicolumn{2}{|c|}{5} & \multicolumn{2}{|c|}{ Total } \\
\hline & N & $\%$ & N & $\%$ & N & $\%$ & $\mathrm{~N}$ & $\%$ & $\mathrm{~N}$ & $\%$ & $\mathrm{~N}$ & $\%$ & $\mathrm{~N}$ & $\%$ \\
\hline $\begin{array}{l}\text { University of } \\
\text { Montreal }\end{array}$ & 58 & 21,5 & 56 & 20,7 & 114 & 42,2 & 73 & 27,0 & 75 & 27,8 & 8 & 3,0 & 270 & 100 \\
\hline HEC & 19 & 21,3 & 19 & 21,3 & 38 & 42,7 & 27 & 30,3 & 18 & 20,2 & 6 & 6,7 & 89 & 100 \\
\hline $\begin{array}{c}\text { Poly- } \\
\text { technique }\end{array}$ & 13 & 27,7 & 10 & 21,3 & 23 & 48,9 & 12 & 25,5 & 12 & 25,5 & 0 & 0,0 & 47 & 100 \\
\hline Total & 90 & 19,1 & 85 & 23,7 & 175 & 42,8 & 112 & 28,3 & 105 & 24,3 & 14 & 4,6 & 406 & 100 \\
\hline
\end{tabular}

Note: 1= Completely Disagree 2= Somewhat Disagree 3= Somewhat Agree 4= Completely Agree 5= Not Applicable

The majority of participants in our focus groups felt this isolation was mainly a result of their difficulties with the French language.

Yes, in terms of communication. Every time, they ask "Do you speak French?" Yet they hear you speaking French. This is a real shock. This is just a detail that could be... that you don't take too seriously, but this, this was a shock. When you're talking with people and you realize that they don't understand you... You are making an effort to listen to them, but they don't understand you. It's a shock because I come from a francophone country and I speak, but they don't understand me. (FG, Polytechnique)

In my case, the first thing is the language. [...] this was one of the things I had to get used to. Also, there is the Quebecois accent, which is a bit different. So it took me several months to adapt and to understand better. It's frustrating because you don't feel... you don't feel like you'll ever be able to speak like the people from here. At work now everything is in English and French - I have to speak both - and it's hard. I can't show off my abilities... my full capacity... because I feel there is a barrier. I'm not sure if I'm the one who created this barrier myself, but in any case it exists. (FG, Polytechnique)

While the issue of French language skills seems to be an underlying factor in the problems experienced by these respondents, a range of other factors also contribute to accentuating feelings of isolation and solitude. Table 7 presents the data pertaining to problems such as discrimination and racism as experienced by the respondents to our online survey.

\section{Table 7 Q48-8 "You have experienced difficulties that you believe were caused by discrimination or racism"}

\begin{tabular}{|c|c|c|c|c|c|c|c|c|c|c|c|c|c|c|}
\hline \multirow{2}{*}{ Q48-8 } & \multicolumn{2}{|c|}{1} & \multicolumn{2}{|c|}{2} & \multicolumn{2}{|c|}{ Total $1+2$} & \multicolumn{2}{|c|}{3} & \multicolumn{2}{|c|}{4} & \multicolumn{2}{|c|}{5} & \multicolumn{2}{|c|}{ Total } \\
\hline & N & $\%$ & $\mathrm{~N}$ & $\%$ & $\mathrm{~N}$ & $\%$ & $\mathrm{~N}$ & $\%$ & $\mathrm{~N}$ & $\%$ & $\mathrm{~N}$ & $\%$ & $\mathrm{~N}$ & $\%$ \\
\hline $\begin{array}{c}\text { University of } \\
\text { Montreal }\end{array}$ & 68 & 25,3 & 69 & 25,7 & 137 & 50,9 & 67 & 27,0 & 49 & 18,2 & 16 & 5,9 & 270 & 100 \\
\hline HEC & 23 & 25,6 & 16 & 17,8 & 39 & 43,3 & 20 & 30,3 & 22 & 24,4 & 9 & 10,0 & 89 & 100 \\
\hline $\begin{array}{c}\text { Poly- } \\
\text { technique }\end{array}$ & 8 & 17,0 & 14 & 29,8 & 22 & 46,8 & 12 & 25,5 & 11 & 23,4 & 2 & 4,3 & 47 & 100 \\
\hline Total & 99 & 22,9 & 99 & 26,8 & 198 & 49,7 & 99 & 28,3 & 82 & 18,5 & 27 & 6,2 & 406 & 100 \\
\hline
\end{tabular}

Note: 1= Completely Disagree 2= Somewhat Disagree 3= Somewhat Agree 4= Completely Agree 5= Not Applicable

Slightly more than half of the respondents stated that they had never, or almost never, felt any discrimination or latent racism directed toward them. In order to verify these results, we asked the following question during the focus groups: "Have you ever experienced any racism"?: 
I work, and I can tell you that I have definitely felt frustrated... At work, they saw me as somebody who doesn't understand... I'm a mechanic. There was a task to carry out as a machine operator, and I said: "I'm able to do this". But they wouldn't give me a chance to do it. They told me: "Hold on, the other guy will do it". (FG, $U$ of M)

Follow-up question: "Did they explain why"?

No. And there was no point in asking why. They would never... There's no point in even asking the question. I understand, but... Maybe they think that we don't understand. Discrimination is no longer something that happens openly. It has become much more subtle. We can't complain about this sort of thing. You'll go to complain and they'll say "no, it meant something else". I tried it. One day they yelled at me so I went to complain, but... We have to live with this. The problem is learning to accept it. (FG, Polytechnique)

In my case, I wouldn't say that it's discrimination or racism, but I find that here at Polytechnique, there are some cases where Professors have a preference for students with the same nationality as them. This happened to me in one class I had, where the Professor was French. It was simple, but we could tell he preferred the French students. He only offered internships to them. He didn't communicate with everybody. It's subtle, but... (FG, Polytechnique)

The questions pertaining to isolation and discrimination were aimed at better understanding whether PRUS respondents considered studying in Quebec to be a step forward in their personal and professional development. Conversely, we asked them whether they felt they had regressed in terms of social status (Table 8).

Table 8 Q48-10 "You feel your social status has declined"

\begin{tabular}{|c|c|c|c|c|c|c|c|c|c|c|c|c|c|c|}
\hline \multirow{2}{*}{ Q48-10 } & \multicolumn{2}{|c|}{1} & \multicolumn{2}{|c|}{2} & \multicolumn{2}{|c|}{ Total $1+2$} & \multicolumn{2}{|c|}{3} & \multicolumn{2}{|c|}{4} & \multicolumn{2}{|c|}{5} & \multicolumn{2}{|c|}{ Total } \\
\hline & $\mathrm{N}$ & $\%$ & $\mathrm{~N}$ & $\%$ & $\mathrm{~N}$ & $\%$ & $\mathrm{~N}$ & $\%$ & $\mathrm{~N}$ & $\%$ & N & $\%$ & $\mathrm{~N}$ & $\%$ \\
\hline $\begin{array}{c}\text { University of } \\
\text { Montreal }\end{array}$ & 59 & 22,2 & 51 & 19,2 & 110 & 41,4 & 77 & 28,9 & 72 & 27,1 & 7 & 2,6 & 266 & 100 \\
\hline HEC & 17 & 19,5 & 14 & 16,1 & 31 & 35,6 & 22 & 25,3 & 26 & 29,9 & 8 & 9,2 & 87 & 100 \\
\hline $\begin{array}{c}\text { Poly- } \\
\text { technique }\end{array}$ & 9 & 18,8 & 12 & 25,0 & 21 & 43,8 & 16 & 33,3 & 6 & 12,5 & 5 & 10,4 & 48 & 100 \\
\hline Total & 85 & 23,0 & 77 & 19,5 & 162 & 42,5 & 115 & 27,2 & 104 & 25,3 & 20 & 4,9 & 401 & 100 \\
\hline
\end{tabular}

Note: 1= Completely Disagree 2= Somewhat Disagree 3= Somewhat Agree 4= Completely Agree 5= Not Applicable

In response to this question most of our respondents felt they had indeed moved forward in their personal and professional lives. Although we did not particularly focus on the differences between the three institutions that make up Campus Montreal, it is worth noting that respondents from HEC Montreal were the least satisfied of the sample. At this point it would be premature to propose any hypothesis as to why the level of satisfaction was slightly lower among PRUS at HEC Montreal. Nevertheless, permanent resident students perceive university studies as an obligatory rite of passage, and consider the real test of their integration to be when it comes time to enter the labor market:

Yes, definitely, because we won't necessarily only have good experiences or only find all the positive aspects of the country that we've been promised. Once we're there, we'll have to integrate ourselves completely, so insertion happens through the job market because this provides you with a fairly stable income. With this income you can then participate in society, buy a house, travel around the country, the province, and play a role in its evolution. Otherwise, for the moment, this is just another step towards that moment; that step hasn't arrived yet. (FG, Polytechnique)

On paper, yes. I have full benefit of all my rights, which also means I have responsibilities to uphold, like all Quebecers and Canadians. But do I feel as Quebecois as Quebecers do? Right now, the real issue for me is the job market. I'm still not sure, because with the job I have now, I didn't have to compete with any Quebecers to get it. So I'm not sure if I got the job because they actually chose me, but I don't think that's the case. I work in a convenience store, it's very basic. But later, once I've finished my studies, it's really going to be about the job market. Once I've made it to this stage, then I'll be able to tick the box for you with certainty, and say "yes, I feel like a Quebecer", or "no, I'm still at the immigrant phase, and I've got a while to go before I consider myself a Quebecer". (FG, Polytechnique) 
Further, some respondents stated that they were considering the possibility of moving to another province in Canada in order to find work commensurate with their training:

“[...] frankly, I think I'm going to leave Quebec. I'm hoping to move away from Quebec” (FG, Polytechnique):

I'm planning on going to Ontario. When I analyze Quebec society and I read journals - I love statistical journals - I make comparisons. I've realized, and I have the evidence, that we are less accepted here than elsewhere. It's not me saying this, it's in the studies. When professionals and studies are saying it, why would I stay in Quebec? These are elements that I take into account. (FG, Polytechnique)

In my case, I'm in the biomedical field. I've looked for placements in the field and I haven't found many. I found more in Ontario, in British Columbia, and other regions. Sure, I've thought about leaving Quebec and looking for another path to help me better integrate the job market. Now I've got an opportunity to go to Toronto for a placement over there, and I think I'm going to take it. (FG, Polytechnique)

Once again, we find that the cornerstone of immigrant individuals' successful integration into the host society is obtaining employment in line with their career aspirations, and that university studies are indeed a viable strategy to achieve this goal. The perceived importance of obtaining a university degree in the host country can explain why many permanent residents choose to begin their pathway to integration through the academic world. Attending a post-secondary institution allows them to make their first contacts with the majority culture, and to evaluate their options in terms of medium- to-long-term socio-professional integration.

\section{Discussion}

An analysis of the data in relation to social interactions among PRUS attending the three universities that make up Campus Montreal resulted in the identification of a number of recurring issues. Our first observation is that PRUS considered the lack of sustained contact between them and students born in Québec to be problematic. The commonly mentioned issues occur in terms of interactions and intergroup relationships as follows:

- Respondents feel that age, ethnic, and religious origins are taken into account in their day-to-day relationships. This places them at a disadvantage particularly during team projects;

- Cultural integration with non-immigrants is hampered by the language barrier. This barrier originates not only in terms of PRUS French language skills and the difficulties they may experience in adapting to the Quebecois accent, but also in the reticence demonstrated by native-born students to socialize with PRUS;

- In line with the previous point, a number of PRUS noted a certain degree of discrimination, latent racism or prejudice during team projects, which ultimately lead them to feel lonely on campus. However, some respondents felt that in classes where the professor imposed pre-defined multicultural teams, they had a more positive experience.

As a result of our analysis, we are able to divide the PRUS into two categories: 1) Those more oriented towards assimilation (Berry et al., 2006) and who demonstrate a more positive perception of the barriers encountered in the integration process and 2) those who struggle to socialize into the host culture and who are more inclined to distance themselves from members of the majority (Harrison \& Peacock, 2010; Middlehurst \& Woodfield, 2007). Following Valentine et al. (2012) and Zhou (2014), our findings reinforce the idea that close interactions on and off the university campus between members of the majority and minorities are extremely important with regards to the social representations and academic perseverance of PRUS.

Beyond the problems mentioned above, it is important to remember that PRUS must overcome other barriers that, while not exclusive to permanent residents, are compounded by their "in-between" status. Indeed, the challenges they face in order to complete their program of study, find a job in their field of study, and, for some, balance school and family life are exacerbated by the fact that these individuals are also going through an adaptation period that can take longer than perhaps anticipated. 
Finally, some of the data shows that permanent resident students experienced fewer problems when family members or acquaintances had preceded them in their return to school. This factor appears to mitigate their lack of interaction with the majority group, and demonstrate that networks of strong ties may have a positive impact, at least in the initial stages of the integration process. Following the inductive approach to our qualitative data (Blackstone, 2012; Burnard et al., 2008), Figure 3 presents the PRUS' academic perseverance process as illustrated by empirical data and the concepts of trust and acculturation (Simmons et al. 2010; Berry, 2005; Berry \& Kim, 1989).

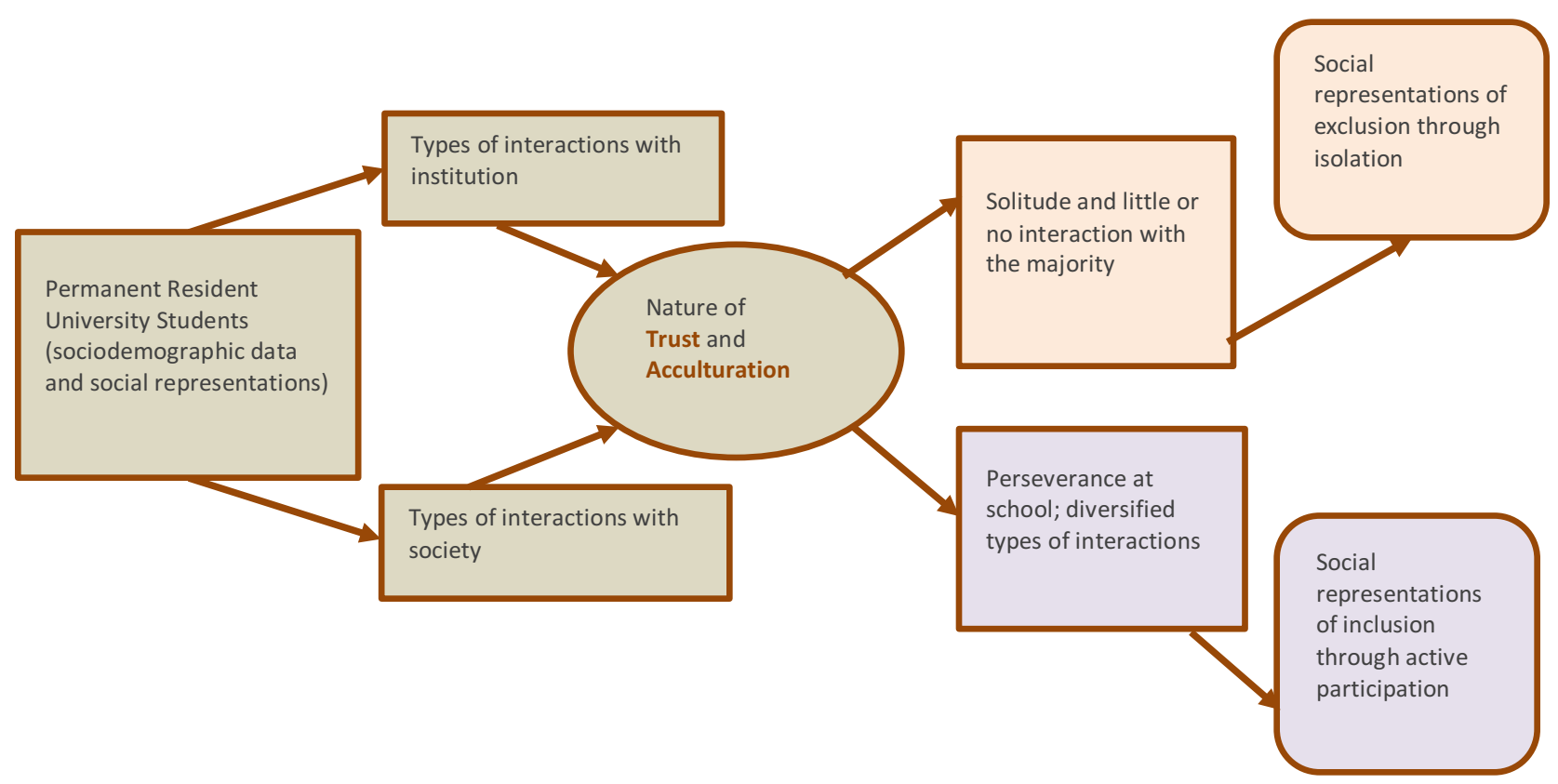

Figure 3. Process of perseverance and social inclusion

With regards to social representations, it is important to note that we are referring to the representations constructed in specific social structures (Moscovici, 1961) and the role they play in the acculturation process and degree of (mis)trust of PRUS in both their academic institution and the host society (Duveen, 2007, 2008; Duveen \& Lloyd, 1990; Markova, 2010). Figure 3 illustrates a constant and reiterative analysis process between the theoretical framework and empirical data.

\section{Limitations}

Several questions merit further research. First, the data presented was not contextualized in relation to the institutional culture. Secondly, given the fact that a number of participants in our focus groups mentioned difficulties related to their French language skills, it would be interesting to carry out a similar study in English language universities in Montreal in order to compare the data. Language is a particularly important issue in the context of Quebec so it would indeed be useful to examine how studying at an English-language university might affect the types and degrees of interactions between PRUS and local students. Thirdly, the relationships between teachers, placement supervisors, and permanent resident students have not been considered in this article. Although we did collect data on this question we deliberately omitted this data in an effort to maintain a certain degree of cohesion and concision. University studies in a migratory context may well be a winning strategy for those hoping to accomplish their professional goals; however, success also depends on whether the university context itself is conducive to harmonious interactions that will, in turn, lead to equal opportunities on the labor market. Furthermore, the link between age and experiences of loneliness and latent racism have not been deeply 
covered in this article. Taking age factors seriously can contribute to develop better adapted institutions and organizational strategies and policies in order to favor the integration of permanent resident university students.

\section{Conclusion}

Through an analysis of the data specific to permanent resident students attending the three universities grouped under Campus Montreal, we were able to identify the most significant aspects of their integration into a university setting. It is important to note that the majority of these students obtained their permanent resident status only after going through a rigorous (and costly) selection process, carried out by various federal and provincial governmental agencies. This selection process is designed to identify those candidates whose skills and qualifications will allow them to quickly enter the workforce.

In light of these results, in the case of PRUS, their integration does not happen as quickly as they and the host society had initially anticipated. Beyond the distinct challenge of returning to school, our PRUS respondents had a rather negative perception of their relationships with the majority group in Quebec. The very nature of these interactions between minorities and the majority group may result in PRUS becoming discouraged, thereby hindering their university experience. Given the low rates of participation in institutional and community associations, PRUS seem to develop a rather negative perception of their chances of successful medium-to-longterm professional integration. In order to alleviate this issue, the province of Québec has attempted to align its immigration policy with the demands of the labor market, yet given the mixed results yielded by our study this point merits further investigation (Arcand et al., 2009; Boudarbat \& Cousineau, 2010). The large number of PRUS in Quebec's university system is, to a certain extent, a good indicator of the barriers these individuals have encountered in their search for employment; more often they choose to return to school rather than become trapped in jobs for which they are over-qualified, or, worse still, languish in unemployment.

University studies in a migratory context may therefore have the reverse effect. They may in fact foreshadow the problems that await PRUS once they have completed their degree, which in turn can have a demoralizing effect on them. While returning to university is commonly viewed as a means of allowing immigrants to update their education and allowing them to compete on an equal footing with those born in the host society, during their studies they encounter the same barriers, systemic or otherwise, that are present in the labor market. If, as we suggest, this were true, the main objective behind their return to school would in fact be detrimental to their trust in the host society and its institutions rather than a springboard to "successful" integration. Finally, our research tends to validate the findings of social psychology studies, particularly those by Berry et al. (2006), Berry (2005), and Berry and Kim (1989) as discussed earlier in this article. However, by grounding this research in a sociological perspective, we shed light on the contribution of the relationships between individuals/institutions and individuals/society as well as the importance of trust and acculturation in the integration process.

\section{Acknowledgements}

The authors would like to thank gratefully the Fonds de recherche du Québec - Société et culture (FRQSC) for providing the funding for the research and Shereef Elshafei et Marilena Liguori for their contributions to the translation and revision of this article.

\section{References}

Adangnikou, N. (2008). Peut-on parler de recherche en pédagogie universitaire, aujourd'hui, en France?. Revue des sciences de l'éducation, 34(3), 601-621.

Alava, S. and Langevin, L. (Eds.). (2001). L'université, un espace d'innovation pédagogique?. Revue des sciences de l'éducation, 27(2), 243-474.

Arcand, S., Lenoir-Achdjian, A. and Helly, D. (2009). Insertion professionnelle d'immigrants récents et réseaux sociaux: le cas de Maghrébins à Montréal et Sherbrooke. Canadian Journal of Sociology/Cahiers canadiens de sociologie, 34(2), 373-402.

Ashwin, P. (2009). Analysing Teaching-Learning Interactions in Higher Education. London, NY: Continuum. 
Asselin, C. (2014). Transformation des représentations sociales et de l'éducation des étudiants allophones, résidents permanents et citoyens canadiens, à l'Université Laval en mode présenciel, et à la TÉLUQ en e-learning : vers la concrétisation du projet d'insertion socio-professionnelle "fort" (Doctoral thesis, Université du Québec à Montréal, Montréal, Canada). Retrieved from http://www.archipel.uqam.ca/7155/.

Béchard, J.-P. (2008). Fondements épistémologiques des auteurs clés de la pédagogie de l'enseignement supérieur: une analyse de trois revues 1976-2003. Revue des sciences de l'éducation, 34(3), 537-568.

Berry, J.W. (2008). Acculturation et adaptation des jeunes immigrants. Canadian Diversity/Diversité Canadienne, 6(2), 56-59.

Berry, J. W. (2005). Acculturation: Living Successfully in Two Cultures. International Journal of Intercultural Relations, 29(6), 697-712.

Berry, J.W. (1997). Immigration, acculturation, and adaptation, Applied Psychology, 46(1), 5-34.

Berry J.W. \& Kim, U. (1989). Acculturation attitudes in plural societies. Applied Psychology, 38(2), 185 - 206.

Berry, J. W., Phinney, J. S., Sam, D. L. and Vedder, P. (2006). Immigrant youth: Acculturation, identity, and adaptation. Applied psychology, 55(3), 303-332.

Blackstone, A. (2012). Principles of Sociological Inquiry: Qualitative and Quantitative Methods (v. 1.0). Nyack, NY: Flat World Knowledge.

Boudarbat, B. and Cousineau, J.-M. (2010). Un emploi correspondant à ses attentes personnelles? Le cas des nouveaux immigrants au Québec. Journal of International Migration and Integration/Revue de l'intégration et de la migration internationale, 11(2), 155-172.

Boudon, R. (Ed.). (1992). Traité de sociologie. Paris: Presses universitaires de France.

Boudon, R. (1988). Individualisme ou holisme : un débat méthodologique fondamental. In H. Mendras and M. Verrat (Eds.), Les champs de la sociologie française (p. 31-45). Paris: Armand Colin.

Bouteyre, E. (2008). Résilience scolaire : De la maternelle à l'université. Paris: Belin.

Burnard, P., Gill, P., Stewart, K. Treasure, E. and Chadwick B. (2008). Analysing and presenting qualitative data. British Dental Journal, 204(8), 429-432.

Chatel-DeRepentigny, J., Montmarquette, C. and Vaillancourt, F. (2011). Les étudiants internationaux au Québec : état des lieux, impacts économiques et politiques publiques (2011s-71). Retrieved from Centre interuniversitaire de recherche en analyse des organisations [CIRANO] website: http://www.cirano.qc.ca/files/publications/2011s-71.pdf

Chiadli, A., Jebbah, H. and De Ketele, J.-M. (2010). L'analyse des besoins en formation pédagogique des enseignants du supérieur au Maroc : comparaison de plusieurs dispositifs. Revue des sciences de l'éducation, 36(1), 4567.

Chicha, M.-T. and Charest, É. (2010). Les programmes d'accès à l'égalité dans les entreprises du secteur privé au Québec : un statu quo décevant. Nos diverses cites, 7, 65-70.

Chicha, M.-T. (2009). Le mirage de l'égalité : les immigrées hautement qualifiées à Montréal. Toronto: Fondation canadienne des relations raciales.

Creswell, J. W. (2009). Research Design. Qualitative, Quantitative and Mixed Methods Approaches (3rd ed.). Thousand Oaks, CA: Sage Publications.

Downey, S. N., van derWerffiL, L., Kecia M. T. and Plaut, V. C. (2015). The role of diversity practices and inclusion in promoting trust and employee engagement, Journal of Applied Social Psychology, 45, 35-44.

Duchesne, C. (2010). À propos de l'accompagnement avant et pendant les stages d'étudiants immigrants inscrits à un programme de formation à l'enseignement. Revue des sciences de l'éducation, 36(1), 95-115.

Alterstice-Revue Internationale de la Recherche Interculturelle, vol. 6, $n^{\circ} 1$ 
Duclos, V. (2011). L'intégration universitaire et sociale d'étudiants tunisiens et marocains inscrits dans une université francophone canadienne. Canadian Journal of Higher Education, 41(3), 101.

Dumouchel, P. (2005). Trust as an Action, Archives of European Sociology, XLVI(3), 417-428.

Durkheim, E. (1895/1964). The Rules of Sociological Method. New York: Free Press.

Duveen, G. (2007). Culture and social representations. In J. Valsiner and A. Rosa (Eds.), The Cambridge Handbook of Sociocultural Psychology (p. 543-559). Cambridge: Cambridge University Press.

Duveen, G. (2008). Social actors and social groups: A return to heterogeneity in social psychology. Journal for the Theory of Social Behaviour, 38(4), 369-374.

Duveen, G. and Lloyd, B. (1990). Introduction. In G. Duveen and B. Lloyd (Eds.), Social Representations and the Development of Knowledge (pp. 1-10). Cambridge: Cambridge University Press.

Granovetter, M. (1973). The strenght of weak ties. American Journal of Sociology, 78(6), 1360-1380.

Gray, J., Galton, M., McLaughlin, C., Clarke, B. and Symonds, J. (2011). The supportive school wellbeing and the young adolescent. Newcastle upon Tyne: Cambridge Scholars Publishing.

Grayson, J.P. (2001). The performance of 'gifted' high school students in university. The Canadian Journal of Higher Education/La revue canadienne d'enseignement supérieur, 31(1), 121-140.

Harrison, N. and Peacock, N. (2010). Cultural distance, mindfulness and passive xenophobia: using Integrated Threat Theory to explore home higher education students' perspectives on 'internationalisation at home'. British Educational Research Journal, 36(6), 877-902.

Hung, H. L. and Hyun, E. (2010). East Asian international graduate students' epistemological experiences in an American University. International Journal of Intercultural Relations, 34(4), 340-353.

Kanouté, F. (2002). Profils d'acculturation d'élèves issus de l'immigration récente à Montréal. Revue des sciences de l'éducation, 28(1), 171-190.

Kanouté, F. and Vatz Laaroussi, M. (Eds). (2008). Relations écoles-familles de minorités ethnoculturelles. Revue des sciences de l'éducation, 34(2).

Kenworthy, J. B., Voci, A., Al Ramiah, A., Tausch, N., Hughes, J, and Hewstone, M. (2016). Building Trust in a Postconflict Society: An Integrative Model of Cross-group Friendship and Intergroup Emotions, Journal of Conflict Resolution, 60(6) 1041-1070.

Loiola, F. A. and Romainville, M. (2008). La recherche sur la pédagogie de l'enseignement supérieur. Où en sommes-nous? Revue des sciences de l'éducation, 34(3), 529-535.

Luhmann, N. (1979). Trust and Power: Two works by Niklas Luhmann. New York: John Wiley and Sons.

Markova, I. (2010). Gerard Duveen on the epistemology of social representations. Papers on Social Representations, 19, 4.1-4.9.

Moscovici, P. (1961). La psychanalyse, son image, son public. Paris: Presses universitaires de France.

Miles, M. B. and Huberman, M. (1994). Qualitative Data Analysis: An Extended Source Book. London: Sage Publication.

Möllering, G. (2006). Trust: Reason, Routine, Reflexivity. Amsterdam: Elsevier.

Nooteboom, B. (2002). Trust: forms, foundations, functions, failures and figures. Cheltenham, PA: Edward Elgar.

Owens, J. and Massey, D. S. (2011). Stereotype threat and college academic performance: A latent variables approach. Social Science Research, 40(1), 150-166.

Rateau, P., Moliner, P., Guimelli, C. and Abric, J. C. (2011). Social Representation Theory. In P.A.M Lang, A.M. Kryglanski and E. Tory Higgins (Eds), Handbook of Social Psychology (p. 480-497). Thousands Oaks, CA: Sage. 
Rege Colet, N. (2008, May). Revalorisation de la formation doctorale: impact des programmes doctoraux sur le développement professionnel. Paper presented at the 25th congress of AIPU, Montpellier, France.

Sauvé, L., Debeurme, G. Martel, V., Wright, A., Hanca, G., Fournier, J. and Castonguay, M. (2007). L'abandon et la persévérance aux études postsecondaires. Rapport final. Québec : Télé-université et Fonds québécois de recherche sur la société et la culture (FQRSC).

Simmons, S. J., Wittig, M. A. and Grant, S. K. (2010). A mutual acculturation model of multicultural campus climate and acceptance of diversity. Cultural Diversity and Ethnic Minority Psychology, 16(4), 468-475.

Taylor-Powell, E. \& Renner, M. (2003). Analyzing Qualitative Data. Program Development and Evaluation. University of Wisconsin-Extension, Cooperative Extension, G-3658-12.

Valentine, K., Prentice, M., Torres, M. F. and Arellano, E. (2012). The importance of student cross-racial interactions as part of college education: Perceptions of faculty. Journal of Diversity in Higher Education, 5(4), 191-206.

Viens, J., Lepage, M. and Karsenti, T. (2010). Vers un changement de culture en enseignement supérieur. Revue des sciences de l'éducation, 36(1), 13-23.

Wang, S. C., Schwartz, S. J. and Zamboanga, B. L. (2010). Acculturative stress among Cuban American college students: Exploring the mediating pathways between acculturation and psychosocial functioning. Journal of Applied Social Psychology, 40(11), 2862-2887.

Zhou, J. (2014). Persistence motivations of Chinese doctoral students in science, technology, engineering, and math. Journal of Diversity in Higher Education, 7(3), 177-193. 